\title{
Periostin as an early marker for elastin mediated vascular smooth muscle cell calcification
}

\author{
Ilanchezhian Shanmugam', Aditi Sinha', Russell A. Norris², Roger Markwald² and Naren Vyavahare ${ }^{1 *}$ \\ *Correspondence: narenv@clemson.edu \\ 'Department of Bioengineering, Clemson University, USA. \\ ${ }^{2}$ Department of Regenerative Medicine and Cell Biology, Medical University of South Carolina, USA.
}

\begin{abstract}
Rationale: Medial vascular calcification (MAC) has been shown to be an active, cell-mediated process. Although several factors have been shown to promote vascular calcification including diabetes and kidney disease, a more complete understanding of the molecular mechanisms underlying the pathogenesis of this disease is needed.

Objective: To find out earliest markers in elastin mediated vascular smooth muscle cell calcification.

Methods and results: We provide evidence that the extracellular matrix protein, periostin, is strongly upregulated during in vitro and in vivo vascular smooth muscle cell calcification. RT-RCR and Western analyses demonstrate that upon stimulation with elastin peptides, rat aortic smooth muscle cells (RASMCs) exhibit a time-dependent increase in periostin expression, which is synergistically enhanced by the addition of transforming growth factor (TGF- $\beta 1$ ). This increase was significantly attenuated by administering either lactose, an elastin-laminin receptor (ELR) antagonist, or the TGF- $\beta 1$ receptor antagonist SB431542. As elastin peptides and TGF- $\beta 1$ have been shown to contribute to RASMC calcification, the potential role of periostin in promoting RASMC calcification was further evaluated. Inhibition of periostin blocked RASMC calcification, whereas overexpression promoted calcification. This periostin-dependent calcification occurs, in part, through the regulation of osteogenic genes: alkaline phosphatase (ALP) and core binding factor 1 (Runx $2 / \mathrm{Cbfa}-1)$. These data were further corroborated in a rat model of aortic calcific disease whereby periostin expression was confined to the calcified abdominal aorta.

Conclusions: Our results demonstrate that periostin is a potent osteogenic molecule in vascular smooth muscle cells and may play a significant role in mediating vascular calcification.
\end{abstract}

Keywords: Arteriosclerosis, medial arterial calcification, smooth muscle cells, osteogenesis, calcific disease, elastocalcinosis

\section{Introduction}

Vascular calcification is a feature of both advanced atherosclerosis and medial artery calcification also known as Monckeberg's sclerosis [1]. Medial arterial calcification (MAC) is the mineral deposition in the media of arteries and is typically associated with elastin. It occurs independently of atherosclerotic plaque [2]. MAC is observed with particularly high frequency in disorders like end-stage renal disease and diabetes mellitus and it is known to increase mortality and amputation risks [3-4]. Both diabetes and chronic kidney disease have been recognized as pro-inflammatory diseases and they increase expression of tumor necrosis factor-alpha (TNF- $a$ ) in arteries which has pro-osteogenic properties [5]. Inflammation in arteries is known to increase matrix degrading enzymes such as matrix metalloproteinases (MMPs) and cathepsins [6-8], which can break down elastic fibers in the media. In diabetic conditions, elevated levels of elastin derived peptides are found in serum [9-11]. It is known that the smooth muscle cells undergo morphological changes to osteoblast-like cells in MAC [12]. We have shown earlier that MMPs play a significant role in elastin degradation and calcification [13]. Rat aortic smooth muscle cells (RASMCs) have shown to increase osteogenic genes with the exposure of elastin fragments along with transforming growth factor, (TGF- $\beta 1$ ) [14]. However, how elastin peptides and TGF- $\beta 1$ triggers this transformation of RASMCs has not been thoroughly investigated. Understanding the role of molecules that regulate the process of elastin mediated vascular calcification is the focus of our study.

Osteoblast-specific factor 2 (OSF2), also referred to as periostin, was first identified using subtractive hybridization techniques on MC3T3-E1 osteoblast-like cells and was thought at that time to be bone-specific [15]. Originally termed osteoblast specific factor-2 (OSF-2); it was renamed periostin due to localized expression in the periosteum and the periodontal ligament [16]. Periostin (postn) expression has been implicated in heart valve morphogenesis [17] and in osteogenesis [18]. Periostin is not detected in adult tissues except under conditions of chronic overload, injury, stress, or pathology. Norris et al., were the first to propose that periostin should be classified as a matricellular protein due to its ability to interact with matrix components to serve a structural role and its ability to interact with cell surface receptors and regulate signaling processes [19].

We wanted to test if periostin is the earliest marker in the osteogenic process in RASMCs. Here we show that RASMCs after exposure to elastin fragments and TGF- $\beta 1$ express high levels of periostin before calcification and blocking of interactions of RASMCs with elastin and TGF- $\beta 1$ reduce the levels back to the normal cells. Moreover, inhibition of periostin blocked RASMC 
Shanmugam et al. Cardiovascular System 2013,

http://www.hoajonline.com/journals/pdf/2052-4358-1-2.pdf

doi: $10.7243 / 2052-4358-1-2$

Table 1. PCR primers used in the study.

\begin{tabular}{lllll}
\hline Gene & Name & Primer (forward) & Primer (reverse) & Accession number \\
\hline$\beta 2-M G$ & $\beta 2$-Microglobulin & CGTGATCTTTCTGGTGCTTGTC & ACGTAGCAGTTGAGGAAGTTGG & NM_012512 \\
CBFA-1 & Core binding factor $\alpha$-1 & CAACCACAGAACCACAAGTGC & CACTGACTCGGTTGGTCTCG & AF053950 \\
ALP & Alkaline phosphatase & TCCCAAAGGCTTCTTCTTGC & ATGGCCTCATCCATCTCCAC & J03572 \\
OCN & Osteocalcin & TATGGCACCACCGTTTAGGG & CTGTGCCGTCCATACTTTCG & NM_013414 \\
POSTN & Periostin & AAAGTAAAAGTTGGCCTTAGCGACC & CAGAAGCTCCCTTTCTTCGCTAGT & NM_001108550 \\
GAPDH & GAPDH & ACCACAGTCCATGCCATCAC & TCCACCACCCTGTTGCTGTA & AB017801 \\
\hline
\end{tabular}

calcification, whereas overexpression promoted calcification.

\section{Methods}

\section{Cell culture and treatments}

Primary rat aortic smooth muscle cells and cell line (Cell Applications Inc, San Diego, CA, USA) from passage 5-8 were used in all experiments. Cells ( $n=6$ wells/group, $6 \times 10^{5} /$ well) were treated with soluble elastin peptide, purified from bovine neck ligament and contained the specific repeating peptide sequence VGVAPG (CB 573, Elastin Products Company, Owensville, MO), recombinant human TGF- $\beta 1$ (PeproTech, Inc., Rocky Hill, NJ, USA), lactose and SB431542 ( Sigma, St. Louis, MO, USA) as follows: $100 \mu \mathrm{g} / \mathrm{ml}$ elastin peptide (elastin group); $10 \mathrm{ng} / \mathrm{ml} \mathrm{TGF-} \beta 1$ (TGF group); $100 \mu \mathrm{g} / \mathrm{ml}$ elastin peptide and $10 \mathrm{ng} / \mathrm{ml}$ TGF- $\beta 1$ (elastin+TGF group); $100 \mu \mathrm{g} /$ $\mathrm{ml}$ elastin peptides and $5 \mathrm{mmol} / \mathrm{L}$ lactose (elastin+lactose group); $10 \mathrm{ng} / \mathrm{ml} \mathrm{TGF}-\beta 1$ and $10 \mu \mathrm{m}$ SB431542 (TGF+SB43 group), and medium alone (control group). Culture media were replaced every 3 days with fresh Dulbecco's modified Eagle's medium supplemented with the appropriate agents in concentrations described above. Gene and protein expression from cell extracts were analyzed after 3 days to 4 weeks as described below. Calcium deposition was evaluated by von Kossa staining of cells maintained in culture for up to 21 days.

\section{Rat aortic calcification model}

Adult male Sprague-Dawley rats weighing $250-300 \mathrm{~g}$ were placed under general anesthesia ( $2-3 \%$ isoflurane) and the infrarenal abdominal aorta were treated periadventitially for 15 minutes with $0.15 \mathrm{~mol} / \mathrm{L} \mathrm{CaCl}$ or $0.15 \mathrm{~mol} / \mathrm{L} \mathrm{NaCl}$ as controls ( $n=6$ rats per group) using the gauze application method described previously [15].

The investigation conforms with the Guide for the Care and Use of Laboratory Animals published by the US National Institutes of Health (NIH Publication No. 85-23, revised 1996). The animal protocols were approved by the Clemson University Animal Research Committee (AUP2011052).

\section{RT-PCR for gene analyses}

Total RNA was isolated from cells using the RNeasy Mini kit (Qiagen, Valencia, CA). For gene expression, we used the primer sets as described in (Table 1). Gene expression in each sample was normalized to the expression of a housekeeping gene (GAPDH) and compared with control samples using the $2^{-\Delta \Delta C T}$ method [21].

Immunofluorescence and western blotting for periostin Standard protocols were used to detect periostin by immunofluorescence and western blotting with rabbit anti-periostin antibody. Details can be found in an online supplement.

\section{Von kossa staining for calcification}

Cells in 3 weeks culture were incubated with $1 \%$ silver nitrate solution and placed under UV light for 20 minutes. After several changes of distilled water, the unreacted silver was removed with $5 \%$ sodium thiosulfate for 5 minutes, and the cells were rinsed and kept in distilled water. The presence of black stain confirmed the presence of calcium phosphate deposits.

\section{Adenoviral and lentiviral construction}

Adenoviral construction was performed as previously described by us [22]. Details can be found in on-line supplement. Selfinactivating replication incompetent viral particles were produced in packaging cells (HEK293T) by co-transfection with compatible packaging plasmids as previously described [23]. The p24 titering assay was utilized to determine shRNA lentiviral titers of $10^{6} \mathrm{TU} / \mathrm{ml}$. A total of 5 shRNA lentiviruses were generated and tested for functionally blocking periostin expression.

\section{Adenoviral and lentiviral shRNA transduction for RASMC}

RASMCs at $50 \%$ confluence were infected with mouse periostin over-expressing adenovirus (PN OX) or periostin knockdown shRNA lentivirus (PN AS) at a concentration of 300 and 10,000 virus particle per cell respectively in serum-free media. After 5 hours, serum-containing growth media were added to the cells. One day prior to virus infection, cells were treated with elastin peptide and TGF- $\beta 1$. Media were replenished every 3 days with fresh test agents. Cells were harvested at 3 and 7 days for RNA and protein extraction respectively. Whole cell lysates were used for western blot to determine protein levels of periostin.

\section{Statistical analysis}

Results are expressed as means \pm SEM. Statistical analyses of the data were performed using single-factor analysis of variance. Statistical differences were determined using the 


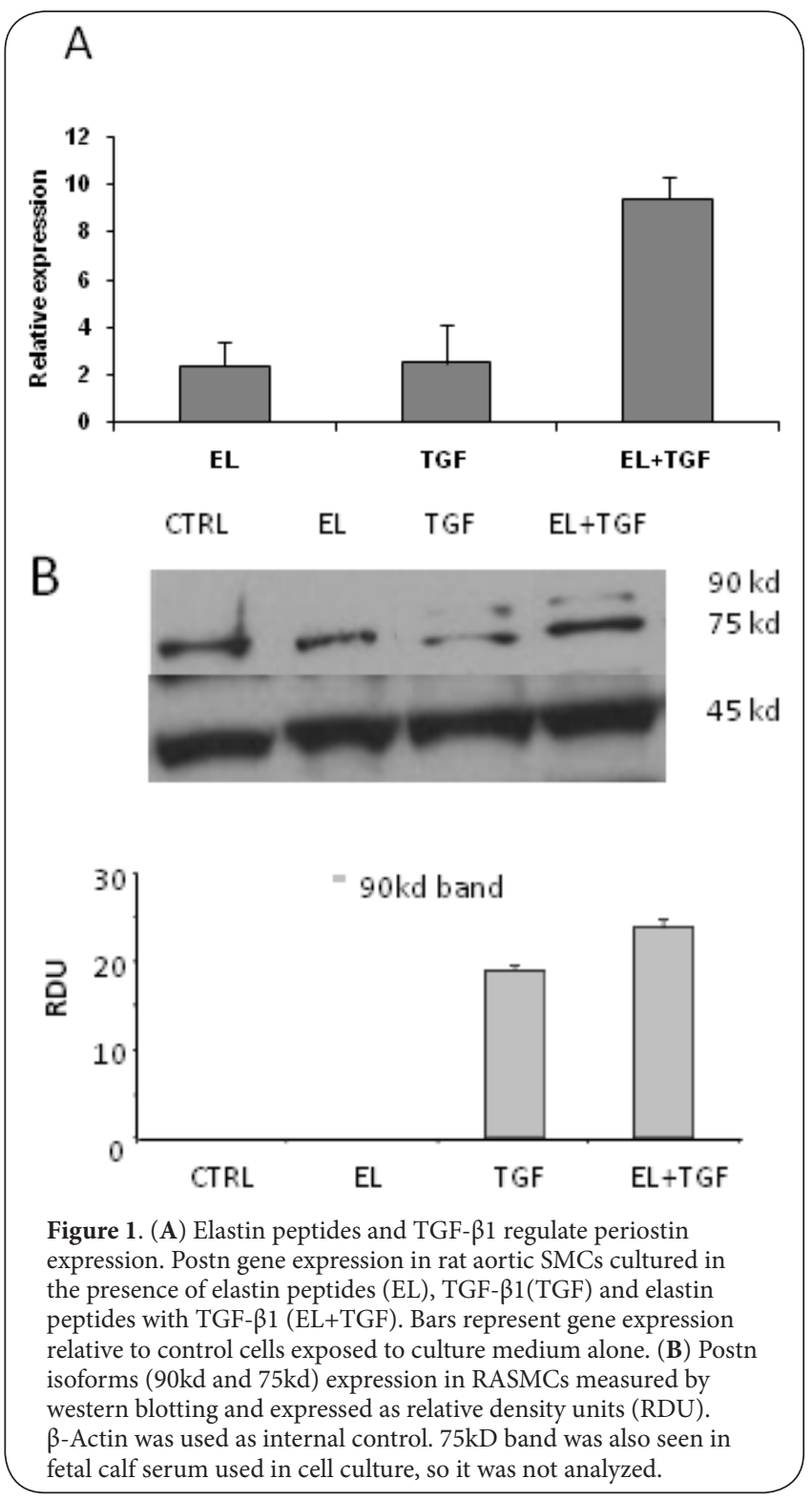

student $t$-test with an a value of 0.05 .

\section{Results}

Elastin peptides and TGF- $\beta 1$ induce expression of periostin in RASMCs

To study if periostin expression is linked to medial calcification, we examined the effect of elastin peptides and TGF- $\beta 1$ on the regulation of periostin expression in smooth muscle cells, a major cell population present in tunica media of arterial wall. We have previously shown that exposure of elastin peptides with TGF- $\beta 1$ to vascular smooth muscle cells leads to osteogenic phenotype [14]. Analysis of periostin mRNA levels at one week indicated increase in the expression of periostin by two fold when RASMC primary cells were treated with elastin peptides or TGF- $\beta 1$ alone whereas the combined treatment of elastin peptides and TGF- $\beta 1$ resulted in a 8 fold robust induction (Figure 1A). Western blot analysis for periostin showed two major variants at 75 and $90 \mathrm{kd}$ in RASMC cells. Treatment with elastin peptides did not alter the expression of periostin protein when compared to control group whereas TGF- $\beta 1$ and combined treatment of elastin peptide with TGF- $\beta 1$ resulted in significant induction of the $90 \mathrm{kd}$ periostin full length isoform (Figure 1B). The more stable $75 \mathrm{kd}$ periostin isoform remained the same in control and experimental groups. It was also found that calf serum used for cell culture experiments showed this $75 \mathrm{kD}$ band, so no further analysis was done for this isoform. Consistent with gene and protein expression, cellular localization of periostin in RASMC showed low but detectable immunofluorescence in untreated, control cells whereas fluorescence was visibly increased after treatment with elastin peptides or TGF- $\beta 1$. Cells cultured in the presence of elastin peptide plus TGF- $\beta 1$ and immunostained with anti-periostin antibodies exhibited high expression of periostin that was distributed in a particulate pattern (Data shown in Supplement figure S1).

\section{Periostin is induced by activation of elastin-laminin} receptor and TGF- $\beta 1$ receptor

The time course of periostin mRNA expression relative to that of GAPDH mRNA in primary rat aortic smooth muscle cells is shown in (Figure 2). At one week after elastin peptide and TGF- $\beta 1$ treatment, periostin mRNA expression rapidly increased, and the expression was 2.2-6.9 folds higher than that measured in controls (Figure 2A). At week two, the expression level in elastin peptide plus TGF- $\beta 1$ group reached a peak with 8.23-fold increase over that of untreated controls, whereas those cultures treated alone with elastin peptide or TGF- $\beta 1$ treatment did not show any increase in the expression over that observed during week 1 (Figure 2B). By week 4, expression in cultures treated with elastin peptides and TGF- $\beta 1$ had declined to a basal level showing no significant difference among any treatment groups compared to untreated control (Figure 2C). Western blot data revealed $90 \mathrm{kd}$ periostin variant was upregulated in TGF- $\beta 1$ or elastin peptide plus TGF- $\beta 1$ treatment only at week one and thereafter at 2 and 4 weeks the $90 \mathrm{kd}$ variant was not found in groups treated with TGF- $\beta 1$ or elastin peptide plus TGF- $\beta 1$ (data not shown).

To determine the involvement of elastin peptide interactions with elastin laminin receptor (ELR) on cells in promoting postn expression after treatment with elastin peptides, cells were incubated with elastin peptides and lactose (an ELR antagonist). Lactose treatment strongly inhibited the expression of the postn mRNA to the level of that observed in untreated controls at all time points, indicating the involvement of elastin laminin receptor in elastin peptide-induced transcription of postn in RASMC (Figure 2). The involvement of TGF- $\beta$ signaling in regulation of periostin expression was examined by using SB-431542, a small molecule that acts as an antagonist for 


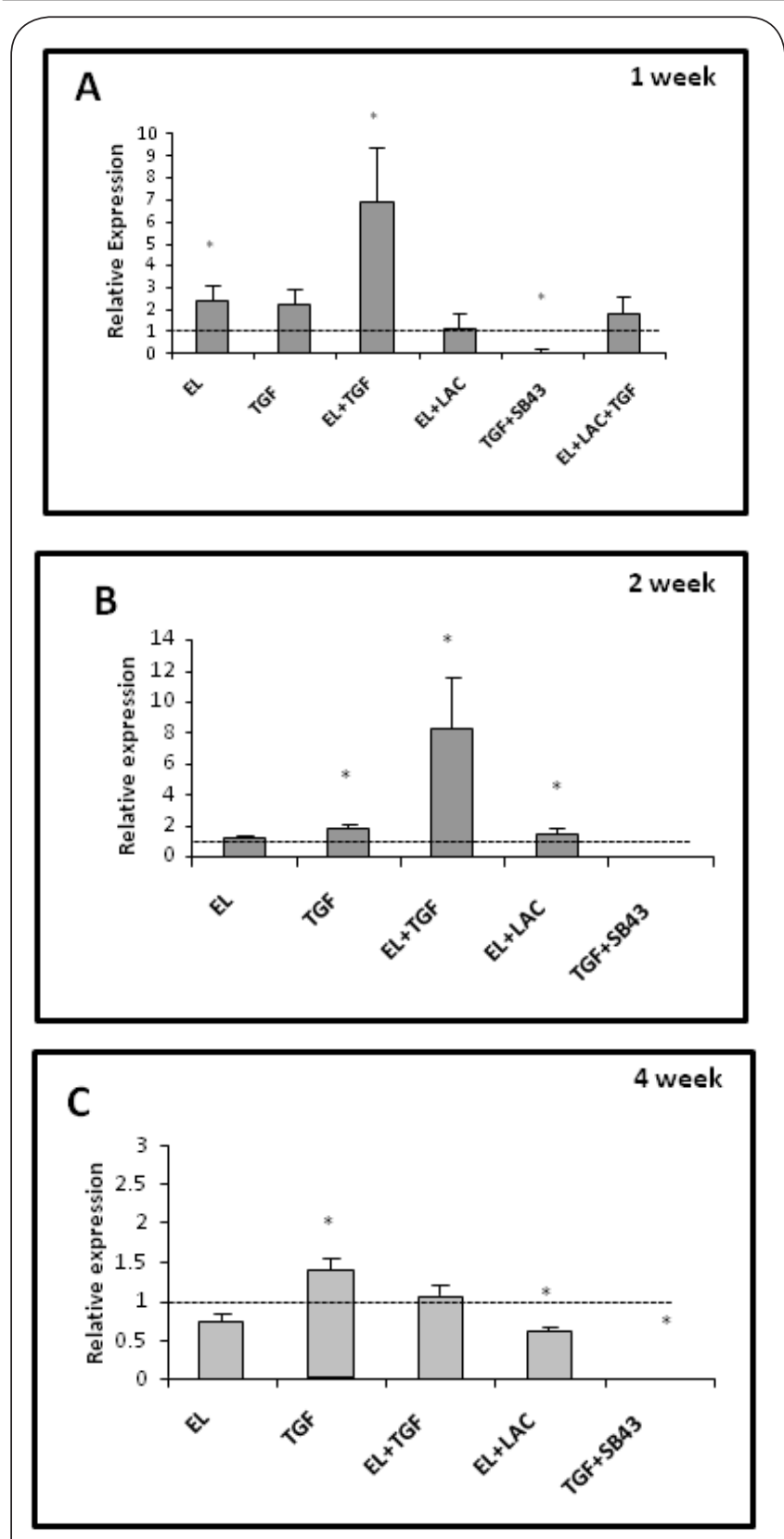

Figure 2. Time course study. Postn gene expression in primary RASMCs cultured in the presence of elastin peptides (EL), TGF- $\beta 1$, EL+TGF- $\beta 1$, elastin peptides with lactose (EL+LAC), TGF- $\beta 1+S B 43$, and EL+LAC+ TGF- $\beta 1$ at $1 \mathrm{wk}$ (A) $2 \mathrm{wks}(\mathbf{B})$ and $4 \mathrm{wks}(\mathbf{C})$.

TGF $\beta$-receptor. SB-431542 treatment of cultured RASMCs almost completely abolished the expression of periostin mRNA induced by TGF- $\beta 1$ at all time points indicating that the dependence of periostin expression upon growth factor stimulation, which is mediated through TGF- $\beta$ type I and type II receptors (Figure 2). To further confirm the upregulation of postn in individual groups, cells were treated with elastin peptide plus TGF- $\beta 1$ and lactose for one week to block the function of ELR. As expected, postn expression was restored back to that level observed in TGF- $\beta 1$ treatment alone
A

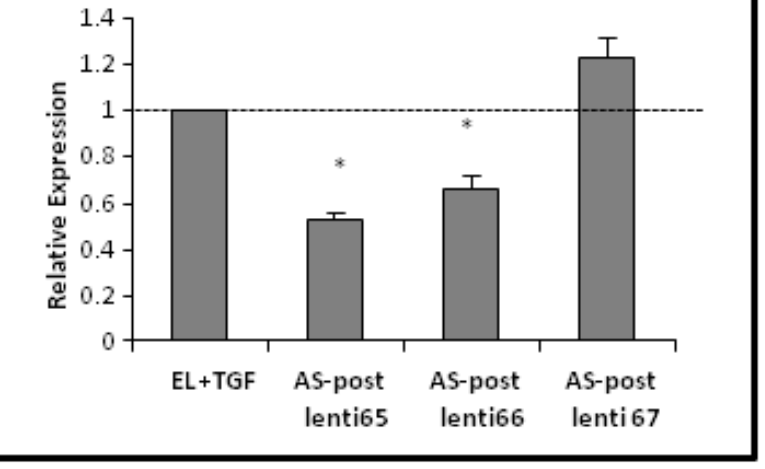

B
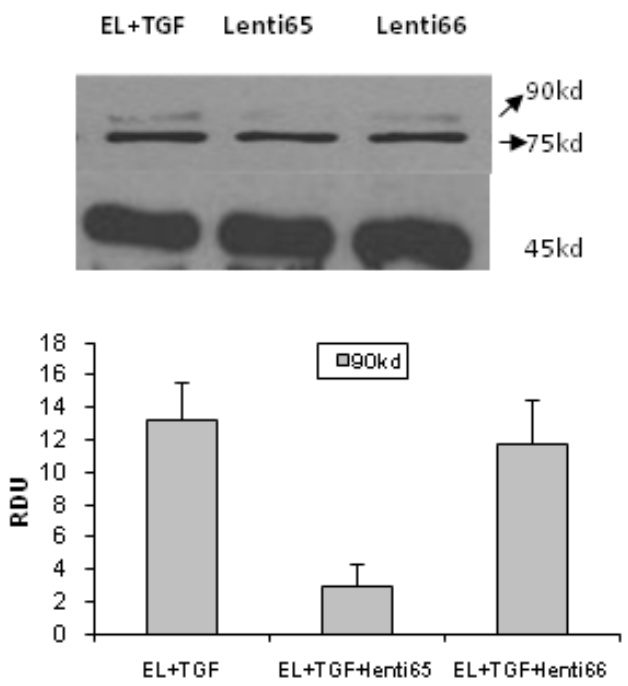

Figure 3. Lentivirus shRNA mediated gene silencing of Postn. RASMC were infected with lentiviral vector shRNA against Postn. Subsequently cells were harvested at 3 and 7 days for RNA and protein extraction respectively. (A) Gene expression of Postn in shPostn infected RASMC exposed to EL+ TGF- $\beta 1$ was determined by Real-time PCR. (B) Knockdown of Postn protein expression in shPostn infected RASMC exposed to EL+ TGF- $\beta 1$ was determined by western blot analysis followed by densitometry for $75 \mathrm{kd}$ and $90 \mathrm{kd}$ isoforms. $\beta$-Actin was used as internal control.

indicating that only combination treatment with elastin peptide plus TGF- $\beta 1$ accounted for the robust induction of postn in RASMC (Figure 2A).

\section{Periostin down-regulation inhibits RASMC osteogenesis and calcification}

To gain a mechanistic understanding of how elastin peptideinduced postn expression correlated with RASMC calcification, we employed shRNA-containing lentiviral vectors to knock down the expression of postn. Three lentiviral vectors 

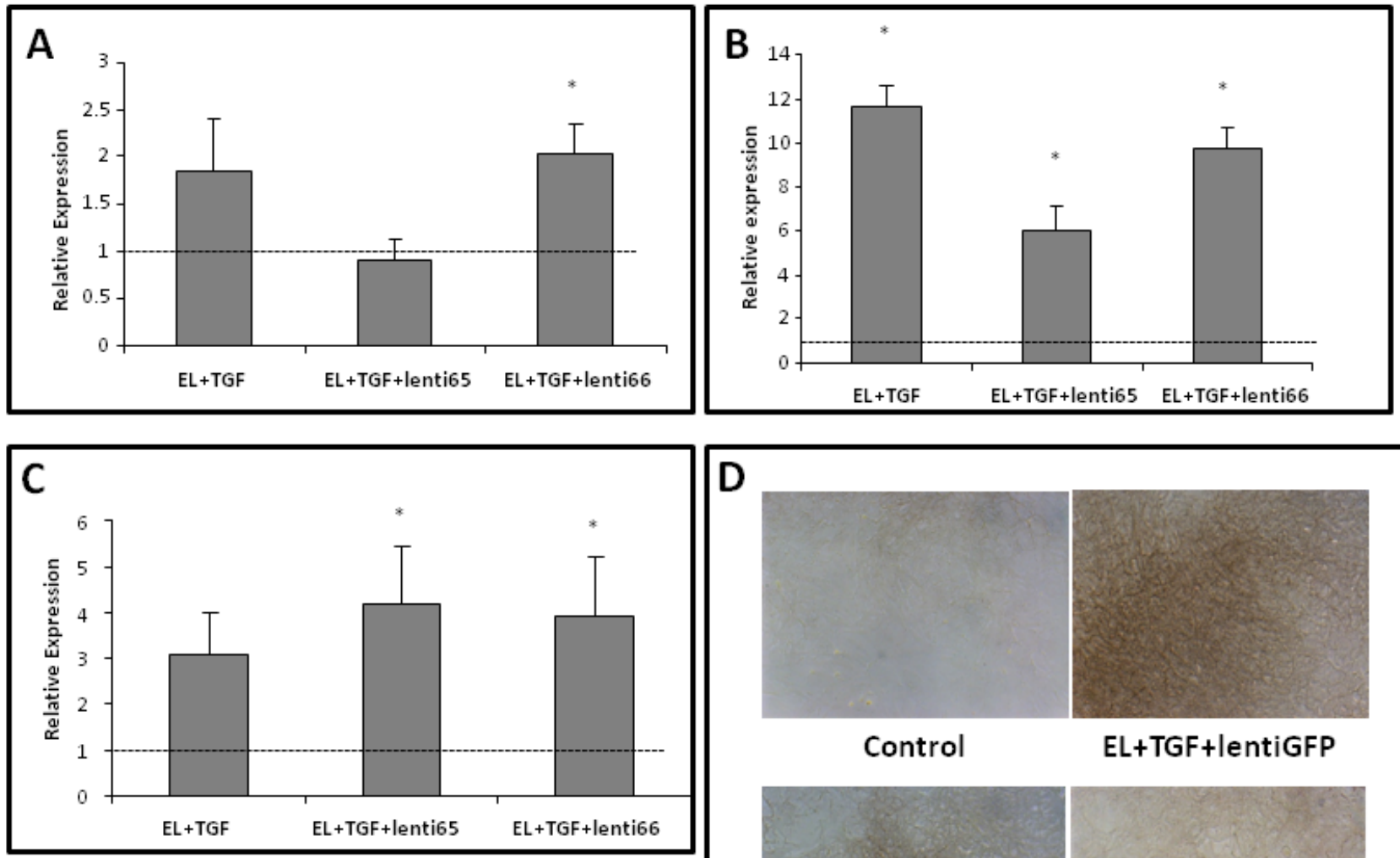

Figure 4. Periostin Down-regulation affects osteogenesis. Expression of bone related molecules (A) core binding factor 1 (Cbfa-1), (B) alkaline phosphatase (ALP), (C) osteocalcin (OCN) in RASMC infected with shPostn exposed to EL+ TGF- $\beta 1$ for 3 days compared with normal control determined by Real time PCR. (D) Periostin downregulation inhibits RASMC calcification. RASMC were treated with EL+ TGF- $\beta 1$ with or without lentiviral vector shRNA against Postn (shPostn) for 3 weeks. In vitro calcification was determined by von Kossa staining. Representative images of two independent experiments are shown. Original magnification, $100 \mathrm{X}$.

namely lenti AS-Postn 65, 66, and 67 were tested. Real-time PCR revealed that periostin mRNA was knocked down by $50 \%$, and $35 \%$ in lentivirus AS-postn- 65 and AS-postn-66 respectively. The third virus, lenti AS-postn-67, did not effectively knockdown the postn expression (Figure 3 A). In parallel with gene expression data, lentivirus AS-postn-65 treatment completely knocked down expression of the $90 \mathrm{kd}$ postn variant whereas infection with lentivirus AS-postn-66 only partially inhibited expression of the $90 \mathrm{kd}$ variant (Figure 3B). Infection with lentivirus AS-postn-65 also diminished expression of periostin protein as revealed by immunostaining (data not shown). None of the Lentivirus treatments had any adverse effect on cell viability in any of our experiments.

As combined treatment of elastin peptides and TGF- $\beta 1$ lead to osteogenesis in RASMCs with increased expression for bone marker proteins [14]; next, we sought to determine whether the inhibited expression of postn affected the expression of bone-related genes after treatment with elastin peptide and TGF- $\beta 1$. To do so, we compared the expression

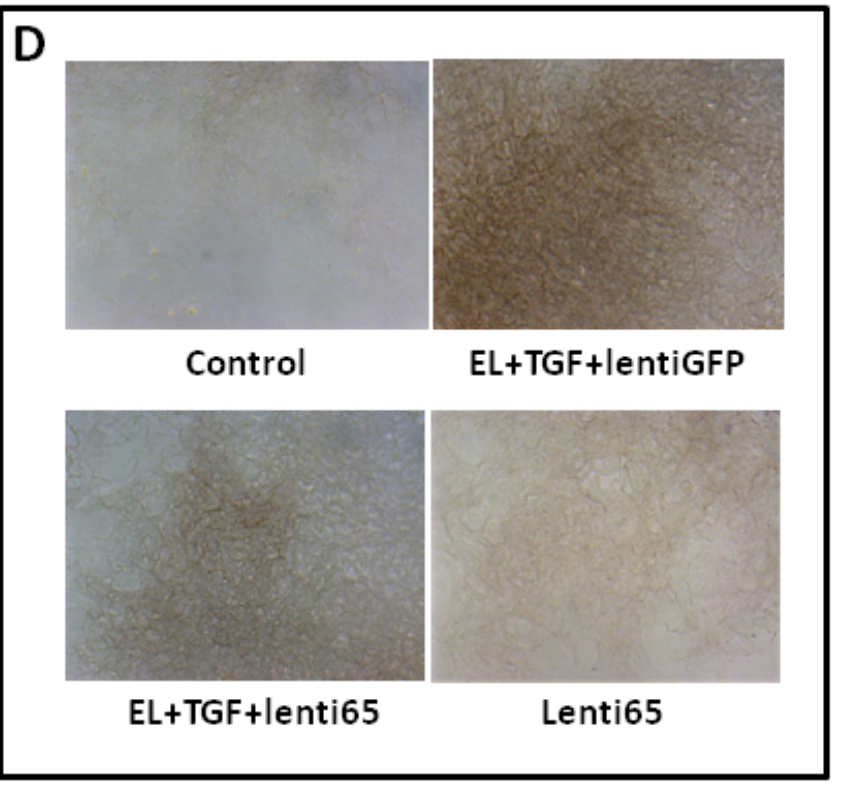

of the marker genes in control RASMC and those treated with silencing vectors for periostin. The two lentiviral vectors (lenti AS-Postn 65 and 66) that were shown to effectively knockdown periostin mRNA were used in these experiments. The expression of osteogenic markers Cbfa-1 (core binding factor 1) and alkaline phosphatase (ALP), that were increased 2 and 12 fold respectively after RASMC were exposed to elastin peptide plus TGF- $\beta 1$ for 1 week (Figure 4A, B) were significantly suppressed by lentivirus treatment.

The elevated expression of the $\mathrm{Cbfa}-1$ gene was down regulated approximately $35 \%$ following shRNA lentivirus 65 treatment, while lentivirus 66 did not down regulate $\mathrm{Cbfa}-1$ gene expression (Figure 4A). Increased gene expression of ALP observed with elastin peptide plus TGF- $\beta 1$ treatment was blocked approximately $50 \%$ and $15 \%$ in cultured cells infected with periostin shRNA lentiviruses 65 and 66, respectively (Figure 4B). The ALP gene expression was reduced 6 fold after periostin knockdown. These two proteins are considered among the earliest lineage markers for an osteoblastic phenotype: periostin knockdown significantly 


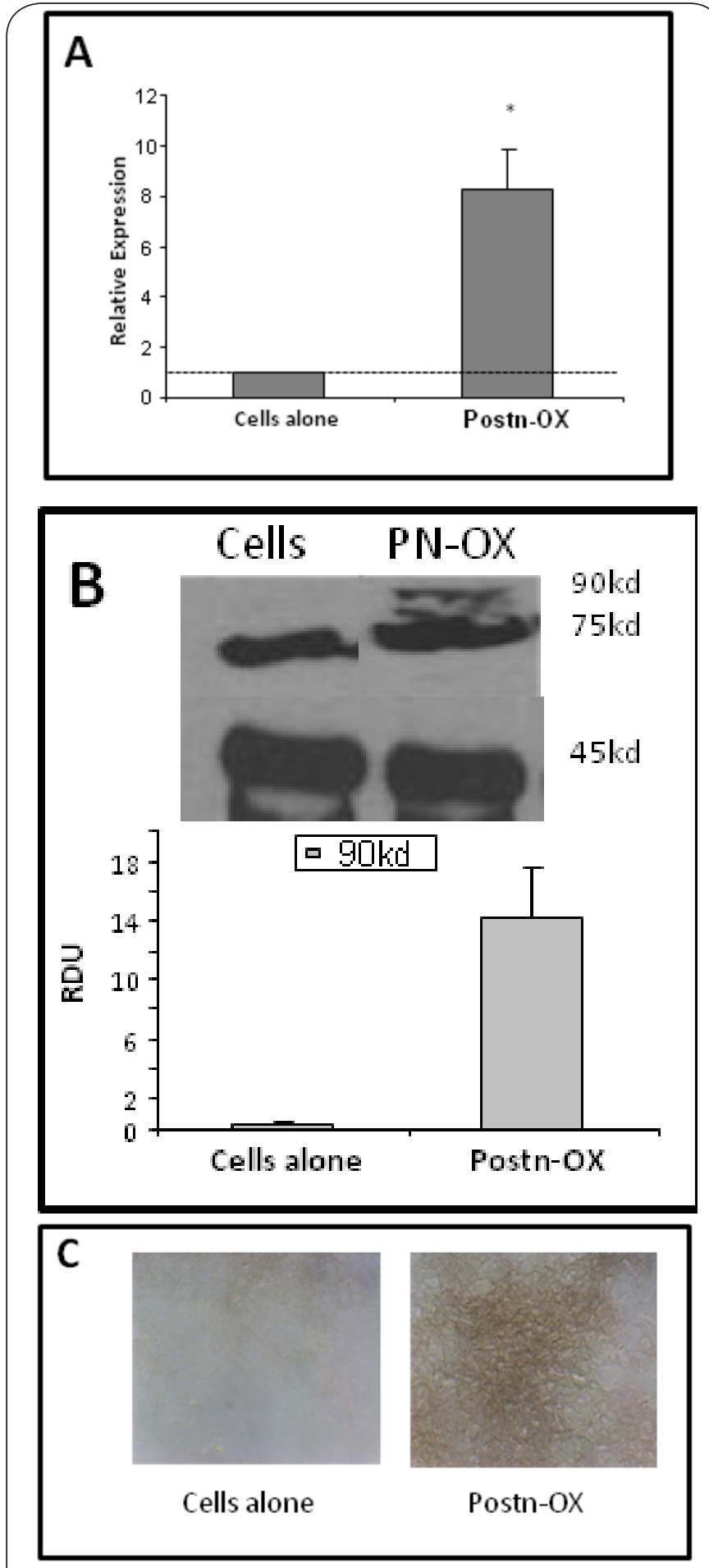

Figure 5. Periostin overexpression increases RASMC calcification. (A) Gene expression of Postn in Ad Postn (PN-OX) infected RASMC was determined by Real-time PCR. (B) RASMCs were infected with Ad Postn (PN-OX) and the expression of postn protein in Ad-Postn transduced cells for 1 week was determined by western blot analysis. Representative blot of three independent experiments is shown. $\beta$-Actin was used as internal control. (C) RASMCs were transduced with Ad-Postn (PN-OX) for 3 weeks. In vitro calcification was determined by von Kossa staining. Representative images of two independent experiments are shown. Original magnification, 100- X. inhibited their expression in cells treated with elastin peptides and TFG- $\beta 1$ indicating periostin played a role early in the process of osteogenesis. The expression of osteocalcin, a protein involved in bone remodeling and a late marker of calcification in osteogenesis was not altered in both lentivirus treatments (Figure 4C).

The early decreased expression of postn in knockdown experiments was sufficient to abrogate RASMC calcification in vitro at 21 days. RASMC infected with a control virus (lenti-EGFP) underwent calcification at 21 days when treated with elastin peptide and TGF- $\beta 1$ as evidenced by von kossa staining (Figure 4D). By contrast, elastin peptide and TGF- $\beta 1$-induced calcification was inhibited when cells were infected with postn inhibitory shRNA lentivirus 65 (Figure 4D). Thus, our data support an essential direct role of postn in elastin peptide and TGF- $\beta 1$ induced RASMC calcification.

\section{Overexpression of periostin increases RASMC calcification}

To determine if periostin alone is sufficient to induce RASMC calcification, we overexpressed periostin in control untreated RASMC cultures by adenovirus carrying a full length periostin CDNA (PN-OX). Real-time PCR gene expression data at 7 days infected with the $\mathrm{PN}-\mathrm{OX}$ virus resulted in an 8 fold induction of postn compared to that of control cells (Figure 5A). This was consistent with the induction observed in the elastin peptide plus TGF- $\beta 1$ group during our various experiments. Similarly, western blot analyses revealed a complete absence of $90 \mathrm{kd}$ variant in control RASMC. In contrast, postn overexpressing adenovirus (PN-OX) infected cells showed a significant increase in the 90 kd periostin variant (Figure 5B). RASMC calcification was enhanced by overexpression of postn; induction of mineralization was observed at an infection rate of 300 pfu/cell at 21 days. RASMC calcification was not affected in RASMC transduced with control virus (Ad-GFP) (data not shown). We confirmed that induction of calcification was strongly correlated with increased levels of postn at both messenger and protein level (Figure 5A, B). These results demonstrate that periostin can induce smooth muscle cell calcification, although the extent of mineralization is much less than that observed in elastin peptide plus TGF- $\beta 1$ treatment.

Periostin expression is found in early stages of aortic medial calcification

We used a rat model of aortic calcific disease to study in vivo periostin expression. The abdominal aorta (AA) injury model involves exposing the infrarenal abdominal aorta through a midline incision and treating it periadventitially with a short (15 min) exposure of calcium chloride $\left(\mathrm{CaCl}_{2}\right)$. We have previously shown that such an injury leads to medial calcification of the abdominal aorta after 1-3 weeks [13]. A salient feature of this model is that the onset of aortic 

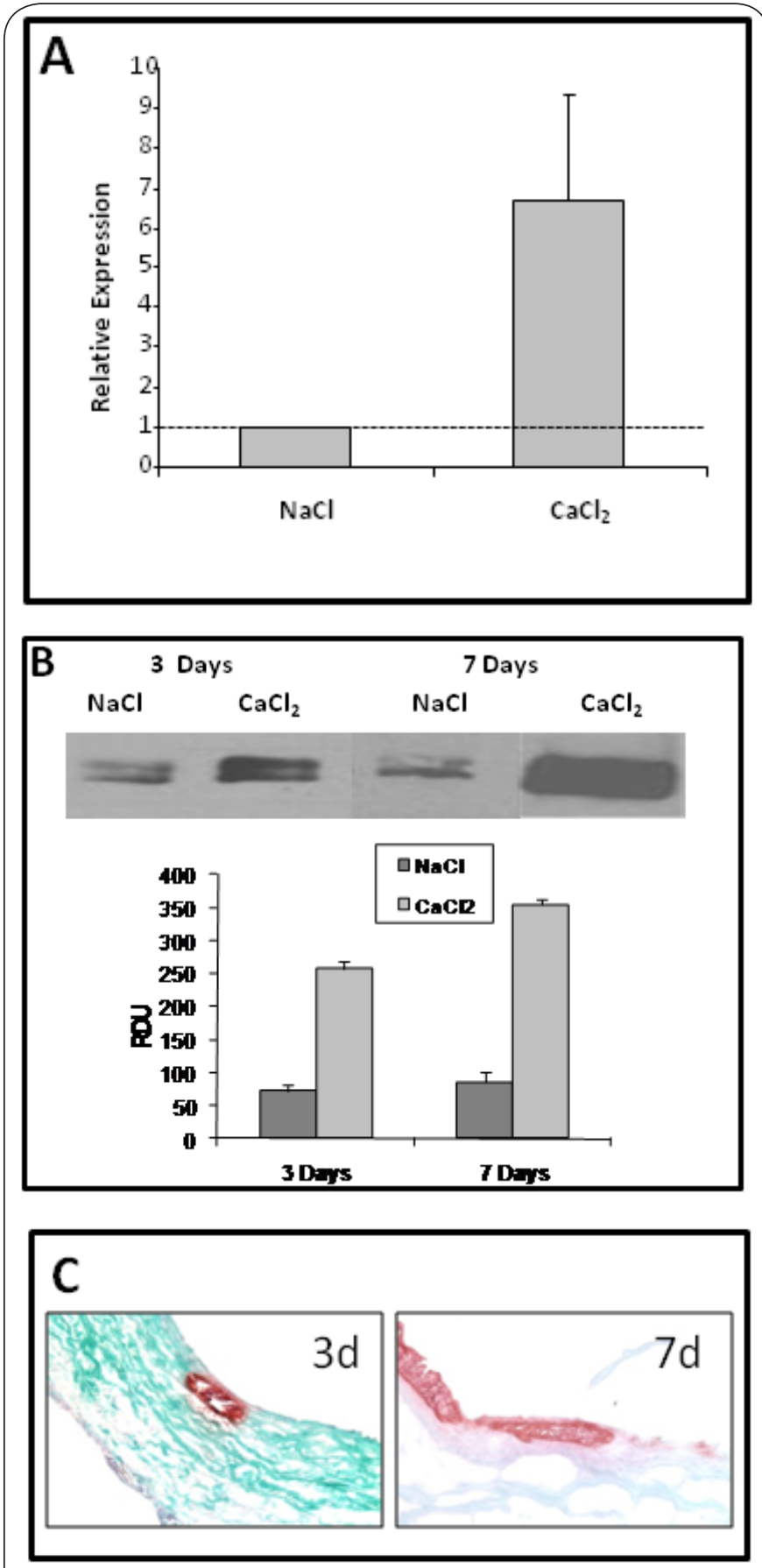

Figure 6. Aortic Injury stimulates postn expression. (A) Postn gene expression in abdominal aorta collected 7 days after treatment with $\mathrm{NaCl}$ or $\mathrm{CaCl} 2$. (B) Postn protein expression in abdominal aorta collected 3 and 7 days after treatment with $\mathrm{NaCl}$ or $\mathrm{CaCl} 2$. (C) Alizarin red staining of aorta shows early calcific deposits in the media of abdominal aorta at 3 and 7 days.

calcification is mainly associated with elastin fibers. Externally applied $\mathrm{CaCl}_{2}$ is washed out within few minutes and does not cause calcium deposits. Inflammation caused by this injury leads to progressive elastin degradation and calcification.
In the present study, a seven fold induction of periostin message was observed after 7 days in $\mathrm{CaCl}_{2}$ treated group when compared to the $\mathrm{NaCl}$ treated control group (Figure 6A). Consistent with the gene expression data; $\mathrm{CaCl}_{2}$ treatment exhibited a 3 and 6 fold induction of postn protein at 3 and 7 days respectively when compared with $\mathrm{NaCl}$ treated control aorta, as evidenced by western blotting. (Figure 6B) Elastin calcification only occurred in $\mathrm{CaCl}_{2}$ treated group and did not occur in $\mathrm{NaCl}$ treated control group. Alizarin red staining of aorta showed early calcific deposits in the media of the abdominal aorta at 3 days and extensive calcification by 7 days (Figure $6 \mathrm{C}$ ). Thus, periostin gene and protein expression was found to occur at the sites where medial aortic calcification occurred.

\section{Discussion}

We investigated the effect of elastin degradation products and TGF- $\beta 1$ on the expression of postn in the smooth muscle cell line and in primary cells. We chose to combine TGF- $\beta 1$ with elastin peptides as TGF- $\beta 1$ is known to be sequestered in elastic fibers and degradation of elastic fiber would release active TGF- $\beta 1$ in the artery. Previous report from our laboratory have shown that in response to elastin peptides and TGF- $\beta 1$, rat aortic smooth muscle cells differentiate into cells that exhibit an osteoblast-like phenotype, characterized by the expression of genes normally restricted to mineralized tissue, including Cbfa- 1 , osteocalcin and alkaline phosphatase [14].

We found a remarkably strong expression of periostin when cells were exposed to combination of elastin peptide plus TGF- $\beta 1$ as evidenced by RT-PCR, western blot, and immuno-fluorescence. Time course studies revealed that the expression level of periostin mRNA transiently increased by 1 week, remained constant at week 2 and returned to the basal level by 4 weeks. However the full length, 90 $\mathrm{KD}$ postn protein was expressed only at $1 \mathrm{wk}$. The lack of expression of periostin protein at 2 and 4 wks in the smooth muscle cells support the hypothesis that the cells at these time points represent a much later stage of differentiation, while strong expression of periostin at $1 \mathrm{wk}$ suggests that the cells at this early time point possess pre-osteoblast like properties. Horiuchi et al., [24] have shown that periostin is a specific marker for preosteoblasts. They showed that postn is a disulfide linked $90 \mathrm{kd}$ a protein secreted by osteoblasts and osteoblast like cell lines. During further differentiation of these cells into mature osteocytes, a decline in the expression of periostin is detectable and osteocytes no longer synthesize this protein [25]. This was also demonstrated in a study of different cell lines in which the preosteoblast to osteocyte ontogeny was shown based on the expression of bone-specific markers. The results indicated that the murine calvarial osteoblast cell line MC3T3-E1 expresses periostin and therefore these cells were interpreted as preosteoblasts. In MLO-A5, MLO-C2, MLO-D1, MLO-D6 and MLO-Y4 cells the 
Shanmugam et al. Cardiovascular System 2013,

production of periostin was diminished and thus these cells were considered at a later stage of differentiation similar to osteocytes $[\mathbf{2 6 , 2 7 ]}$. In consistent with these studies, our data therefore suggest that periostin expression is restricted only at early stages of RASMC differentiation.

The high postn expression was effectively inhibited by lactose, an elastin laminin receptor (ELR) antagonist and by SB431542, a TGF- $\beta 1$ receptor antagonist. Elastin peptides are known to interact with cells through ELR. Lactose is a selective elastin laminin receptor (ELR) antagonist [28]. SB431542 is a potent and highly selective small-molecule inhibitor of TGF- $\beta 1$-dependent signaling [29]. Thus, the present study demonstrated that elastin peptide or TGF- $\beta 1$ mediated stimulation of postn mRNA expression in SMCs in vitro is receptor dependent and is mediated by TGF- $\beta$ R 1 and ELR. This effect was further confirmed when cells were concomitantly treated with elastin peptide, lactose and TGF- $\beta 1$ to block the function of ELR. As expected, postn expression was restored back to that level observed in TGF- $\beta 1$ treatment alone indicating that both ELR and TGF- $\beta$ R 1 are involved in this upregulation. More work is needed to find out how the crosstalk between these two transduction pathways takes place to increase periostin gene expression.

To test if periostin is one of the earliest markers in osteogenesis, RASMC cells exposed to elastin peptides and TGF- $\beta$ were treated with lentiviral shRNA to knockdown the expression of periostin. The use of viral vectors to inhibit protein activity, is an accepted technique, used successfully by others [22]. We tested the expression of osteoblast-specific markers, such as alkaline phosphatase (ALP), Cbfa- 1 and osteocalcin, to provide insight into the role of periostin in osteogenesis. Cbfa-1 and ALP were markedly reduced by shRNA treatment. Cbfa-1 expression in RASMCs serves as an early, definitive marker of osteoblastic differentiation, the initial step in vascular calcification. Cbfa- 1 is a transcription factor that controls the expression of a number of proteins associated with osteoblastic differentiation, including osteocalcin, OPN, and type I collagen [30]. ALP is a functional, phenotypic marker of osteoblasts, and ALP activity is often used as a molecular marker for vascular calcification, as it is an early indicator of mineral matrix deposition [31]. ALP activity is crucial to hydroxyapatite formation during endochondral ossification [32]. In medial calcification, SMCs express higher levels of ALP [33]. Alkaline phosphatase modulates vascular calcification by decreasing levels of inorganic pyrophosphate, which is a substrate for ALP and a recognized potent inhibitor of vascular calcification $[34,35]$. As both Cbfa- 1 and ALP expression was down regulated by shRNA mediated downregulation of postn in RASMCs, postn may be an upstream of ALP and Cbfa-1. Osteocalcin is a marker of late stage osteoblast differentiation, and the lack of this gene reportedly causes an increase in boneformation in mice [36]. Interestingly in the present study, we found that the stimulatory effect of elastin peptides on the expression of osteocalcin was not reduced in postn knockdown cells, suggesting that postn knockdown effect is more specific, inhibiting only the early markers of differentiation and not the late markers such as osteocalcin.

Reduction in the expression of bone specific markers in cells with reduced (knocked down) expression of postn also led to decreased RASMC calcification at a later stage. RASMC cells began to form nodules at 7 days after elastin peptide and TGF- $\beta 1$ treatment; the multilayered cells then became polygonal in shape and formed nodules. Von Kossa staining showed that the majority of the nodules were darkly stained in RASMC cells at 21 days after the elastin peptide and TGF- $\beta 1$ treatment. However, significantly less mineralization was observed in postn knockdown lentivirus treated cells indicating periostin depletion inhibit calcification and suppress the induction of osteoblast like phenotype in smooth muscle cells. Not only knockdown of postn reduced calcification, but we also found that overexpression of postn with transduction of adenovirus encoding postn was sufficient to induce calcification of RASMCs. This is consistent with a previous study showing that adenoviral gene transfer of periostin like factor (PLF) an isoform related to postn enhanced the osteogenic differentiation and mineralization of primary osteoblast cells [37]. Our results strongly indicate that postn plays an essential role in elastin mediated RASMC calcification in vitro, and postn overexpression alone is sufficient to induce RASMC calcification in absence of elastin peptides and TGF- $\beta 1$.

Encouraged by the robust induction of postn in RASMC cell culture studies, we were interested in studying the regulation of postn in circulatory animal model where medial vascular calcification is observed. Previous studies from our laboratory have shown that $\mathrm{CaCl}_{2}$ mediated aortic injury leads to elastin specific medial calcification in the abdominal aorta of rats [13]. In the present study we saw a several fold induction of periostin at gene and protein at 3 and 7 days after injury along with medial calcification as compared to $\mathrm{NaCl}$ treated control group, which did not lead to elastin calcification. We have observed higher elastin degradation and increased TGF- $\beta 1$ levels in the calcified regions of the artery in this animal model of vascular calcification. Thus our cell culture results were corroborated in a circulatory model showing that postn expression is the critical early event in early stage medial calcification.

In summary, the present study provides the first evidence of the role of Postn in elastin mediated RASMC calcification in vitro and medial calcification in vivo in a rat model. We also demonstrated that calcification in RASMC proceeds through osteogenic differentiation with the induction of postn that alters the expression of downstream bone specific proteins that lead to calcification. However, more in vivo clinical data is needed to further investigate the role of postn in vascular calcification.

\section{Additional files \\ Supplement figure S1}


Shanmugam et al. Cardiovascular System 2013,

\section{Competing interests}

The authors declare that they have no competing interests.

\section{Authors' contributions}

IS performed most of the experiments, AS helped with western blots, and RAN and RM helped with adenoviral vector studies for periostin over-expression. NRV was involved in planning and execution of the experiments and writing of the manuscript.

\section{Acknowledgement and funding}

Authors wish to thank Dr. Agneta Simionescu for her help in experiments. This work was funded partially by NIHHL61652 (to NV), HL33756-27 (to RRM) and P20GM103444.

\section{Publication history}

Received: 17-Feb-2013 Revised: 14-Mar-2013

Accepted: 16-Mar-2013 Published: 03-Apr-2013

\section{References}

1. Trion A and van der Laarse A: Vascular smooth muscle cells and alcification in atherosclerosis. Am Heart J 2004, 147:808-14. | Article | PubMed

2. Proudfoot $D$ and Shanahan $C M$ : Biology of calcification in vascular cells: intima versus media. Herz 2001, 26:245-51. | Article | PubMed

3. Amann K: Media calcification and intima calcification are distinct entities in chronic kidney disease. Clin J Am Soc Nephrol 2008, 3:1599-605. | Article I PubMed

4. Soor GS, Vukin I, Leong SW, Oreopoulos G and Butany J: Peripheral vascular disease: who gets it and why? A histomorphological analysis of 261 arterial segments from 58 cases. Pathology 2008, 40:385-91. | Article I PubMed

5. Al-Aly Z: Medial vascular calcification in diabetes mellitus and chronic kidney disease: the role of inflammation. Cardiovasc Hematol Disord Drug Targets 2007, 7:1-6. | Article | PubMed

6. Galis ZS, Muszynski M, Sukhova GK, Simon-Morrissey E and Libby P: Enhanced expression of vascular matrix metalloproteinases induced in vitro by cytokines and in regions of human atherosclerotic lesions. Ann N Y Acad Sci 1995, 748:501-7. | Article | PubMed

7. Chung AW, Yang HH, Sigrist MK, Brin G, Chum E, Gourlay WA and Levin A: Matrix metalloproteinase- $\mathbf{2}$ and $\mathbf{- 9}$ exacerbate arterial stiffening and angiogenesis in diabetes and chronic kidney disease. Cardiovasc Res 2009, 84:494-504. | Article | PubMed

8. Uemura S, Matsushita H, Li W, Glassford AJ, Asagami T, Lee KH, Harrison DG and Tsao PS: Diabetes mellitus enhances vascular matrix metalloproteinase activity: role of oxidative stress. Circ Res 2001, 88:1291-8. | Article | PubMed

9. Bizbiz $L$, Alperovitch $A$ and Robert $L$ : Aging of the vascular wall: serum concentration of elastin peptides and elastase inhibitors in relation to cardiovascular risk factors. The EVA study. Atherosclerosis 1997, 131:738. I Article | PubMed

10. Fulop T, Jr., Wei SM, Robert $L$ and Jacob MP: Determination of elastin peptides in normal and arteriosclerotic human sera by ELISA. Clin Physiol Biochem 1990, 8:273-82. I Article I PubMed

11. Nicoloff G, Petrova C, Christova P and Nikolov A: Detection of free elastin-derived peptides among diabetic children. Atherosclerosis 2007, 192:342-7. | Article | PubMed

12. Johnson RC, Leopold JA and Loscalzo J: Vascular calcification: pathobiological mechanisms and clinical implications. Circ Res 2006, 99:1044-59. | Article | PubMed

13. Basalyga DM, Simionescu DT, Xiong W, Baxter BT, Starcher BC and Vyavahare NR: Elastin degradation and calcification in an abdominal aorta injury model: role of matrix metalloproteinases. Circulation 2004, 110:3480-7. | Article | PubMed Abstract | PubMed Full Text

14. Simionescu A, Philips $K$ and Vyavahare $N$ : Elastin-derived peptides and TGF-beta1 induce osteogenic responses in smooth muscle cells. Biochem Biophys Res Commun 2005, 334:524-32. I Article I PubMed
15. Takeshita S, Kikuno R, Tezuka K and Amann E: Osteoblast-specific factor 2: cloning of a putative bone adhesion protein with homology with the insect protein fasciclin I. Biochem J 1993, 294 ( Pt 1):271-8. | Article | PubMed Abstract | PubMed Full Text

16. Kruzynska-Frejtag A, Wang J, Maeda M, Rogers R, Krug E, Hoffman S, Markwald RR and Conway SJ: Periostin is expressed within the developing teeth at the sites of epithelial-mesenchymal interaction. Dev Dyn 2004, 229:857-68. I Article I PubMed

17. Norris RA, Kern CB, Wessels A, Moralez El, Markwald RR and Mjaatvedt $\mathrm{CH}$ : Identification and detection of the periostin gene in cardiac development. Anat Rec A Discov Mol Cell Evol Biol 2004, 281:1227-33. | Article | PubMed

18. Yoshioka N, Fuji S, Shimakage M, Kodama K, Hakura A, Yutsudo M, Inoue $\mathrm{H}$ and Nojima $\mathrm{H}$ : Suppression of anchorage-independent growth of human cancer cell lines by the TRIF52/periostin/OSF-2 gene. Exp Cell Res 2002, 279:91-9. | Article | PubMed

19. Norris RA, Borg TK, Butcher JT, Baudino TA, Banerjee I and Markwald RR: Neonatal and adult cardiovascular pathophysiological remodeling and repair: developmental role of periostin. Ann N Y Acad Sci 2008, 1123:30-40. | Article | PubMed

20. Lindner V, Wang Q, Conley BA, Friesel RE and Vary CP: Vascular injury induces expression of periostin: implications for vascular cell differentiation and migration. Arterioscler Thromb Vasc Biol 2005, 25:77-83. | Article | PubMed

21. Livak KJ and Schmittgen TD: Analysis of relative gene expression data using real-time quantitative PCR and the 2(-Delta Delta $C(T))$ Method. Methods 2001, 25:402-8. I Article | PubMed

22. Norris RA, Damon B, Mironov V, Kasyanov V, Ramamurthi A, MorenoRodriguez R, Trusk T, Potts JD, Goodwin RL, Davis J, Hoffman S, Wen X, Sugi Y, Kern CB, Mjaatvedt CH, Turner DK, Oka T, Conway SJ, Molkentin JD, Forgacs $G$ and Markwald RR: Periostin regulates collagen fibrillogenesis and the biomechanical properties of connective tissues. J Cell Biochem 2007, 101:695-711. I Article I PubMed Abstract I PubMed Full Text

23. Zufferey R, Dull T, Mandel RJ, Bukovsky A, Quiroz D, Naldini L and Trono $D$ : Self-inactivating lentivirus vector for safe and efficient in vivo gene delivery. J Virol 1998, 72:9873-80. | Article | PubMed Abstract | PubMed Full Text

24. Horiuchi K, Amizuka N, Takeshita S, Takamatsu H, Katsuura M, Ozawa H, Toyama Y, Bonewald LF and Kudo A: Identification and characterization of a novel protein, periostin, with restricted expression to periosteum and periodontal ligament and increased expression by transforming growth factor beta. J Bone Miner Res 1999, 14:1239-49. | Article | PubMed

25. Allen MR, Hock JM and Burr DB: Periosteum: biology, regulation, and response to osteoporosis therapies. Bone 2004, 35:1003-12. | Article I PubMed

26. Bonewald LF: Establishment and characterization of an osteocytelike cell line, MLO-Y4. J Bone Miner Metab 1999, 17:61-5. I Article | PubMed

27. Kato Y, Boskey A, Spevak L, Dallas M, Hori M and Bonewald LF: Establishment of an osteoid preosteocyte-like cell MLO-A5 that spontaneously mineralizes in culture. J Bone Miner Res 2001, 16:162233. I Article I PubMed

28. Hinek A, Wrenn DS, Mecham RP and Barondes SH: The elastin receptor: a galactoside-binding protein. Science 1988, 239:1539-41. | Article I PubMed

29. Hjelmeland MD, Hjelmeland AB, Sathornsumetee S, Reese ED, Herbstreith $\mathrm{MH}$, Laping NJ, Friedman HS, Bigner DD, Wang XF and Rich JN: SB-431542, a small molecule transforming growth factor-betareceptor antagonist, inhibits human glioma cell line proliferation and motility. Mol Cancer Ther 2004, 3:737-45. | Article I PubMed

30. Xiao G, Jiang D, Ge C, Zhao Z, Lai Y, Boules H, Phimphilai M, Yang X, Karsenty $\mathrm{G}$ and Franceschi RT: Cooperative interactions between activating transcription factor 4 and Runx2/Cbfa1 stimulate osteoblast-specific osteocalcin gene expression. J Biol Chem 2005, 280:30689-96. | Article | PubMed 
Shanmugam et al. Cardiovascular System 2013,

http://www.hoajonline.com/journals/pdf/2052-4358-1-2.pdf

31. Sinha S, Eddington $\mathrm{H}$ and Kalra PA: Vascular calcification: lessons from scientific models. J Ren Care 2009, 35 Suppl 1:51-6. | Article | PubMed

32. Boyan BD, Schwartz $Z$ and Swain LD: Matrix vesicles as a marker of endochondral ossification. Connect Tissue Res 1990, 24:67-75. | Article I PubMed

33. Shanahan CM, Cary NR, Salisbury JR, Proudfoot D, Weissberg PL and Edmonds ME: Medial localization of mineralization-regulating proteins in association with Monckeberg's sclerosis: evidence for smooth muscle cell-mediated vascular calcification. Circulation 1999, 100:2168-76. | Article | PubMed

34. Moss DW, Eaton RH, Smith JK and Whitby LG: Association of inorganicpyrophosphatase activity with human alkaline-phosphatase preparations. Biochem J 1967, 102:53-7. | Article | PubMed Abstract | PubMed Full Text

35. Lomashvili KA, Cobbs S, Hennigar RA, Hardcastle KI and O'Neill WC: Phosphate-induced vascular calcification: role of pyrophosphate and osteopontin. J Am Soc Nephrol 2004, 15:1392-401. | Article | PubMed doi: 10.1097/01.ASN.0000128955.8312

36. Ducy P, Desbois C, Boyce B, Pinero G, Story B, Dunstan C, Smith E, Bonadio J, Goldstein S, Gundberg C, Bradley A and Karsenty G: Increased bone formation in osteocalcin-deficient mice. Nature 1996, 382:448-52. | Article | PubMed

37. Zhu S, Barbe MF, Liu C, Hadjiargyrou M, Popoff SN, Rani S, Safadi FF and Litvin J: Periostin-like-factor in osteogenesis. J Cell Physiol 2009, 218:584-92. | Article | PubMed

\section{Citation:}

Shanmugam I, Sinha A, Norris R, Markwald R and Vyavahare N: Periostin as an early marker for elastin mediated vascular smooth muscle cell calcification.

Cardiovascular System 2013, 1:2.

http://dx.doi.org/10.7243/2052-4358-1-2 